\title{
Multi-Frequency Electrical Impedance Measurement on a Wooden Disc Sample
}

\author{
Zoltán VIZVÁRI $^{\mathrm{a}^{*}}-$ Tibor KISS $^{\mathrm{a}}$ - Kálmán MÁTHÉ ${ }^{\mathrm{b}}-$ Péter ODRY $^{\mathrm{c}}-$ \\ Csaba VÉR ${ }^{\mathrm{a}}-$ Ferenc DIVÓS $^{\mathrm{d}}$ \\ ${ }^{a}$ Smart City Technologies Research Group, Szentágothai Research Centre, Univesity of Pécs, Hungary \\ ${ }^{\mathrm{b}}$ Pollack Mihály Faculty of Engineering and Information Technology, Univesity of Pécs, Hungary \\ ${ }^{c}$ Department of Computer Systems and Control Engineering, College of Dunaújváros, Hungary \\ ${ }^{\mathrm{d}}$ Institute of Physics and Electrotechnique, Simonyi Károly Faculty of Engineering, Wood Sciences and \\ Applied Arts, University of West-Hungary, Sopron, Hungary
}

\begin{abstract}
Non-invasive measurement techniques are widely used for the investigation of living tree and wood material. Principles and methods from other fields of science form the basis of these techniques. Electrical impedance measurement, which is adopted mainly from applied geophysics, plays an important role in the investigation of living trees and wood material. Unlike other measurement techniques that provide mainly physical information, electrical impedance measurement is able to gather either physical or chemical information. There are several published accounts of the use of Electrical Impedance Tomography mainly for examining internal decay, estimation of sapwood, and heartwood width. The advantages of the method are its low costs and rapid execution; however, low spatial resolution is still one of the most glaring limits of the method. Use of a new, self-developed, high resolution measurement system provides new opportunities to gain better insights into the characterisation of wood material. As well as high accuracy and resolution, the measurement system is able to operate in a wide frequency range. This expands the examined parameters making it possible to extend the gained information and develop new methods for the investigation of living trees and wood material. The aim of our publication is to introduce some experimental results in the investigation of spatial resolution our system measured on a wooden disc.
\end{abstract}

multi-frequency Electrical Impedance Measurement / spatial resolution / wood disk

Kivonat - Fakorongok multi-frekvenciás elektromos impedancia mérése. Az él fák és faanyagok vizsgálatához különböz méréstechnikai eljárásokat alkalmaznak. Ezek alapját els sorban más tudományterületekr 1 hozott elvek és módszerek képezik. Az elektromos ellenállás (impedancia) mérés, melyet a geofizikai gyakorlatból adoptáltak, ezek között nem kevésbé fontos szerepet tölt be, ugyanis míg a mérési módszerek többsége szerkezeti, fizikai információt szolgáltat, addig az elektromos módszerek a fizikai mellett kémiai információszerzésre is alkalmasak. Az Elektromos Impedancia Tomográfiát több ízben publikálták él fák esetében üregek, illetve szíjács és geszt vastagság becslésre. Bár a mérési eljárás el nyei közé sorolható a relatív alacsony költségigény és gyorsaság, összevetve azonban más képalkotó eljárásokkal, a kisebb térbeli felbontás szab határt az egyes alkalmazások elterjedésének. Egy új, saját fejlesztés nagy felbontóképesség mér eszköz alkalmazása új lehet ségeket nyújthat a felbontás javításában és a faanyag jellemzésében. A mér eszközre jellemz, hogy a nagy pontosságú és felbontóképesség méréseket igen széles

* Corresponding author: vizvariz@gmail.com; H-7624 PÉCS, Ifjúság útja 20. 
frekvencia-tartományban képes kivitelezni. Ez egy új dimenziót nyit meg az él fa és faanyag vizsgálat módszertanában, mely egy új mérési eljárás fejlesztését alapozhatja meg. Jelenlegi publikációnk célja mér eszközünk térbeli felbontásának kísérleti ellen rzése faanyagon.

multi-frekvenciás elektromos impedancia mérés / térbeli felbontás / fakorong

\section{INTRODUCTION}

Non-destructive measurement techniques play a crucial role in the evaluation of living trees. These methods are developed mainly from imaging techniques used in applied geophysics (Szalai et al. 2002) and medical diagnostics. Imaging techniques from the adaptation of seismic methods are the most improved. (Divos et al. 1994) These measurements are made by using acoustic waves. The result of acoustic tomography is generally an approximation of the spatial distribution of wave velocity in the investigated tree. There are several other nondestructive imaging methods published mostly for the detection of decay in trees. (Divos et al. 1991, Nicolotti et al. 2003, Bucur 2003) These investigation methods are X-ray, gamma ray, computer tomography, nuclear magnetic imaging, thermal techniques, ground penetrating radar, microwave methods and electrical tomography.

Electrical tomography methods are used in geophysical sub-surface explorations by performing on-surface measurements. As an early wood material investigation method, electrical resistivity measurements were published in (Shortle et al. 1997). The researchers (Shortle et al. 1997) examined the spatial distribution of electrical resistance in a wooden disc. The authors performed the published measurements on samples taken from the wooden disc. Later, other authors published electrical measurement methods applied to several goals, for example finding discoloured wood, red-heart in beech (Weihs, 2001), detection of decay in trees (Dubbel et al. 1999; Rust et al. 2007, Brazee et al. 2011); estimation of sapwood and heartwood width (Bieker et al. 2010.); variation of electrolytes in Quercus robur (Bieker et al. 2010.). For these purposes, Electrical Resistance Tomography (ERT) as a non-invasive measurement technique was used. In the case of these investigations, the measurements and evaluations were performed with single frequency measurements.

In multi-frequency Electrical Impedance Tomography, we create an electrical field in the segment of a living tree that is to be investigated. This field depends on spatial distribution of admittance (or impedance), which is characteristic for the tissue of the tree. Admittance (reciprocal of impedance) is a physical quantity, which measures how easily an investigated material allows the injected current to flow through it. The electrical field can be characterised by the measuring of electrical potentials on the boundary of domain. Through data collection and evaluation, the spatial distribution of admittance (or impedance) can be approximated. The speciality of mfEIT is the injected current, which is a monochromatic sine wave. Thus the measured material can be characterised in time and frequency domain. (Woo et al. 2007) Testing in time domain includes the EIT in classical meaning. By adding the measurements in frequency domain, we can measure the transfer function of the object. Thus we gain a more extended evaluation method for the investigation of living trees and wood materials that includes the measurement of spatial distribution of admittance (or impedance) depending on the frequency. The investigated structure responds dissimilarly in every frequency point.

The aim of mfEIT is to locate several types of anomalies in living trees in the best spatial resolution possible. To achieve this, equipment with high resolution and an appropriate electrode configuration is essential. A publication of Beck - Williams (1996) compares the advantages and disadvantages of several techniques applied in industrial tomography. 
According to their statements (1996), EIT is a relatively cheap, quick, suitable, and simple imaging technique; but there is a need for research in the refinement of spatial resolution which is relatively small when compared to other techniques. The spatial resolution of EIT is determined as the ratio of diameter of the smallest object that can be located and the average diameter of material in which the measurements are made. According to Beck Williams (1996), the EIT spatial resolution is about 10\%, the worst imaging technique in industrial tomography. A spatial resolution of $10 \%$ means that EIT as an imaging method has the capability to localize a $20 \mathrm{~mm}$ object (anomaly) in a $200 \mathrm{~mm}$ diameter sample.

\section{MATERIALS AND METHODS}

The measurement system consists of a high precision generator and a measuring board. The generator, which can be operated as a current or voltage generator, provides a low-distortion monochromatic sine wave for the excitation of a measured object in a large frequency range, between $20 \mathrm{mHz}$ and $90 \mathrm{kHz}$. The measurement board is in general a data acquisition system that measures the real and imaginary part of complex voltages with 48 bit resolution. Amplitude measurement accuracy is $1 \mathrm{ppm}$ and phase measurement accuracy is $0.01^{\circ}$. The system can execute spectral (Fourier spectrum of signal), spectroscopic, and tomographic measurements. With wobbler function it is possible to record impedance spectrums and transfer functions. Tomographic measurements are realized with parallel measurements using 8 channels. By adding a multiplexer board, it is possible to extend the number of channels up to 64. Our primary aim is to develop a modern tomographic method, which is called multi-frequency Electrical Impedance Tomography (mfEIT), for the investigation of living trees using a measurement system with high accuracy and resolution. In our paper we demonstrate the results of the experiments dedicated to spatial resolution determination in wood material.

In order to verify the suitability of our measurement system for mfEIT measurement in living trees and wood material, we performed an experiment for spatial resolution determination. We measured wood samples several times - first without an anomaly and later with an artificial anomaly. A fresh (green) slice of hornbeam (Carpinus betulus) was chosen for the experiment. The height of the disc was $11 \mathrm{~cm}$; the average diameter was $20 \mathrm{~cm}$. The measurement setup can be seen in Figure 1.

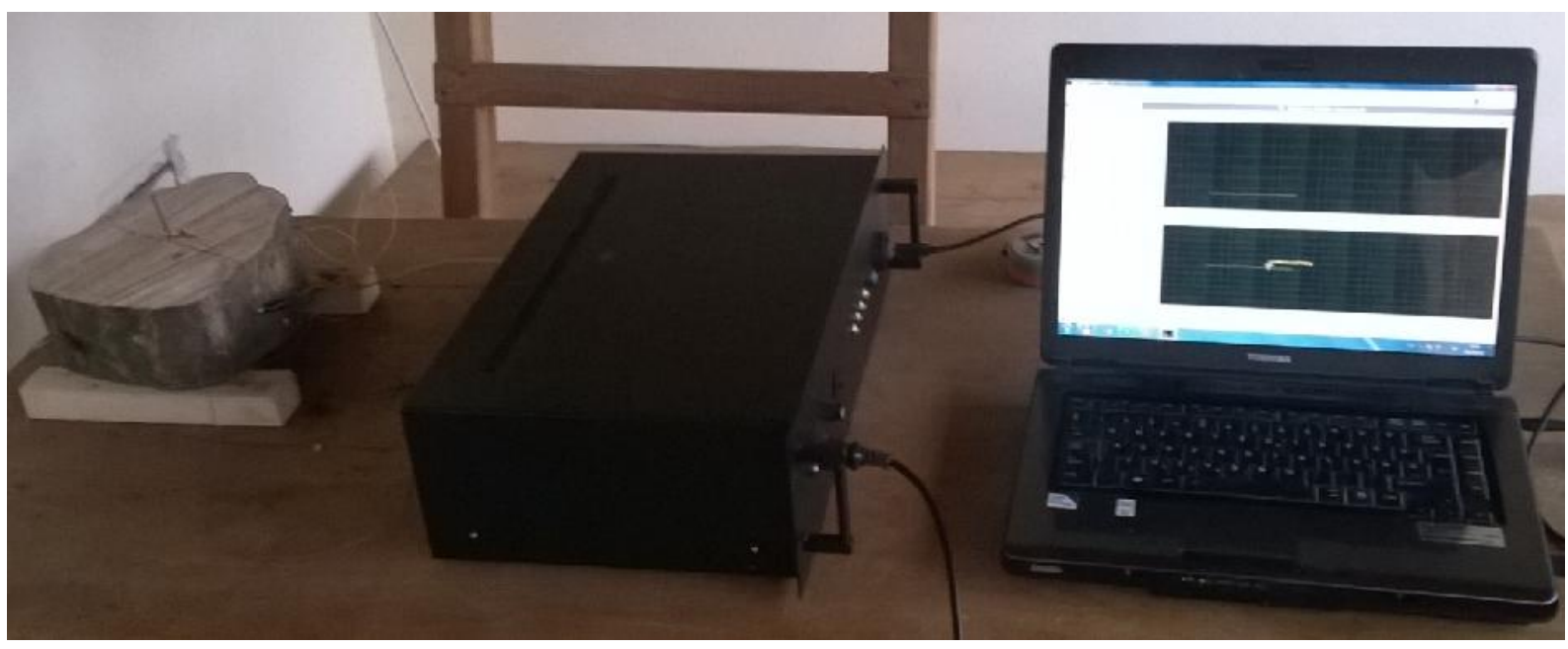

Figure 1. Measurement layout for experiments in hornbeam 
In the first case the log was measured without anomalies. These recordings were used as background information in the evaluation. Then an anomaly - a small hole - shown in Figure 2, was made in the sample. Later, additional holes were drilled in the hornbeam disk. The holes were placed on the line between the source electrodes; the distance of the negative pole of generator and the centre of the bore was $140 \mathrm{~mm}$. The diameter of the first hole was $8 \mathrm{~mm}$ (4\% of the sample diameter); this was increased to $10 \mathrm{~mm}(5 \%), 12 \mathrm{~mm}(6 \%), 16 \mathrm{~mm}(8 \%)$, $20 \mathrm{~mm}(10 \%)$.

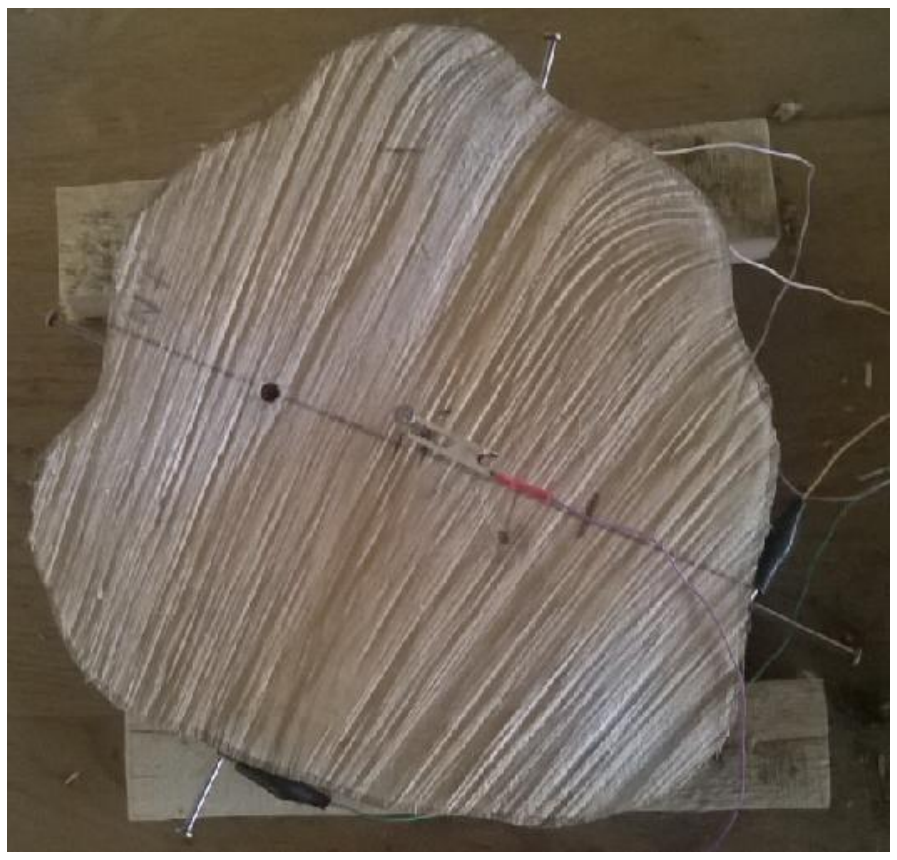

Figure 2. $8 \mathrm{~mm}$ diameter bore, drilled into slice of hornbeam for experimental measurements

In this study we applied only 4 electrodes in addition to a ground electrode which was located at the centre of the disk. In the case of in-situ measurements, we will place the ground electrode in the soil, near the tree. The applied electrode configuration is shown in Figure 3.

The electrode configuration shown in Figure 3 is called a null array in geophysical practice (Szalai et al. 2002), which indicates some types of anomalies very sharply. If the sought anomaly doesn't exist, the measured values are minimal corresponding to the inhomogeneity of measured material. When an anomaly can be found in the investigated material, the measured potential values respond with very sharp changes. Figure 3 shows that the current generator was connected to the source electrodes (1 and 2) and the potentials were measured on electrodes 3 and 4 . The lines, linking the source (1 and 2) and measuring (3 and 4) electrodes were perpendicular. That results in the appropriate sensitivity that is characteristic for null arrays.

We measured the complex voltages on the source and measuring electrodes by applying a current generator. For calculations we applied the complex voltage measured on source for reference voltage. The measurements were done with swept sine in a range of $0.1 \mathrm{~Hz}-90 \mathrm{kHz}$, in 100 frequency points. The voltages, measured on electrodes 3 and 4 , are dissimilar to the reference voltages in every frequency point. This difference, caused by the measured material, can be characterized by calculating the attenuation of amplitudes and phase difference. (Figure 4). 


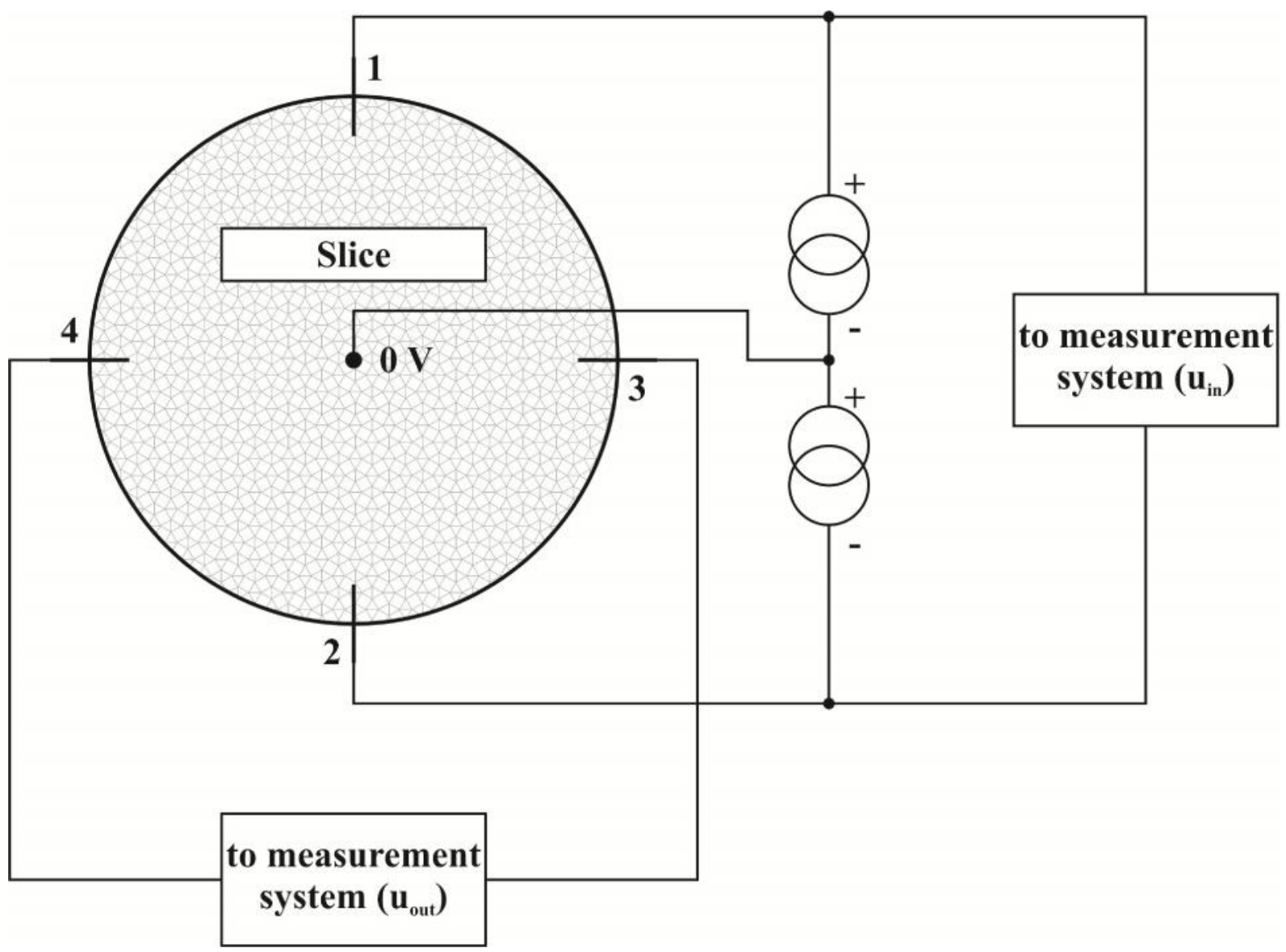

Figure 3. The applied electrode configuration

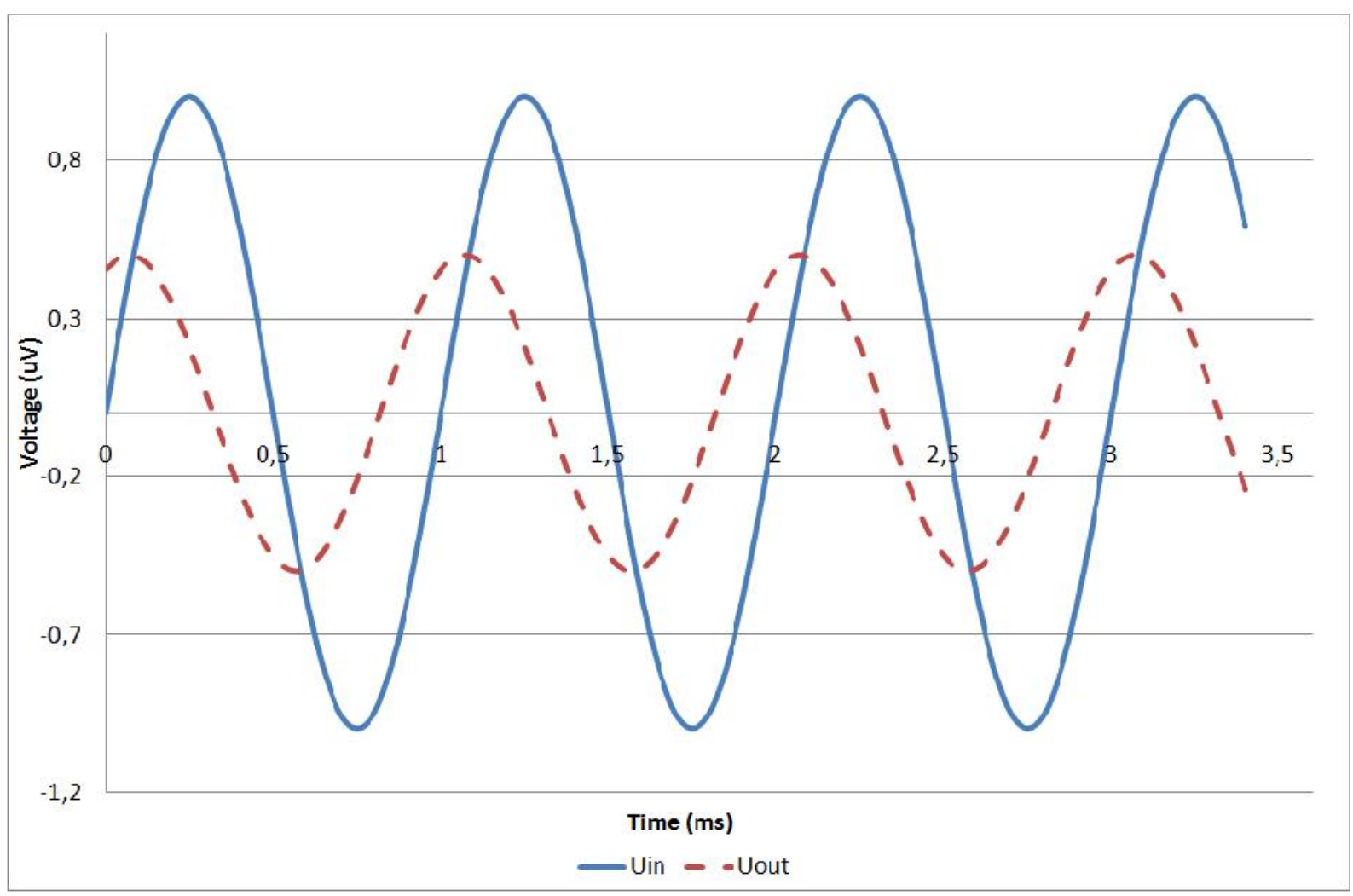

Figure 4. Illustration of the difference between the measured and reference voltages measured in linear material 
The collected data is characteristic for the transfer function of the tested material. Thus the evaluation of collected data is possible in this way:

$$
\begin{gathered}
A=-20 \cdot \lg \frac{\left|u_{\text {out }}\right|}{\left|u_{\text {in }}\right|} \\
\varphi=\varphi_{\text {in }}-\varphi_{\text {out }}
\end{gathered}
$$

where

$A$ is the attenuation of signal in measured material $(\mathrm{dB})$

$\left|u_{\text {out }}\right|$ is the magnitude of voltage measured on electrodes 3 and 4

$\left|u_{i n}\right|$ is the magnitude of voltage measured on source electrodes

$\varphi$ is the phase difference

$\varphi_{\text {out }}$ is the phase of voltage measured on electrodes 3 and $4\left(^{\circ}\right)$

$\varphi_{\text {in }}$ is the phase of voltage measured on source electrodes $\left(^{\circ}\right)$

We assumed homogeneous electrical properties in the radial - tangential plane, although in reality, according to our experimental data, there is about a $10 \%$ relative difference between radial and tangential directions. At this stage we tried to ignore this effect, but in the future we will need to take this into consideration.

\section{RESULTS}

The first measurements were made in a log of hornbeam without artificial defect. The aim of these experiments was to gain information of the electrical stability of the measurement setup. These measurements were used as background data as well. For the characterisation of stability of the measurement set-up, single frequency recordings were made with $1 \mathrm{~Hz}, 5 \mathrm{~s}$ averaging time in $60 \mathrm{~s}$ lengths. Coefficients of variation $(\mathrm{CV})$ were calculated. The $\mathrm{CV}$ values in general were better than $0,5 \%$ (at $1 \mathrm{~Hz}$ ). Thereafter the transfer functions were measured. In every experimental case the transfer function was recorded 3 times. From these the average $\mathrm{CV}$ values were calculated, which were better than $0,05 \%$ for magnitude and better than $10 \%$ for phase (calculated on the total frequency range).

The measured transfer functions for all experimental cases are shown in Figure 5.

Figure 5 shows the attenuation and phase versus frequency - called a Bode diagram. Both of these characteristics are specific for the investigated material. Thus, for the evaluation of the measurements, both of the curves have to be taken into consideration. The attenuation is represented in $\mathrm{dB}$ unit and the phase in degree. According to Figure 5, the attenuation curves have the same character. At low frequency, they have maximal values and they decrease monotonically. The shape of attenuation curves is specific for the material properties. The difference between maximum and minimum attenuation values is $3.29 \mathrm{~dB}$ in the case of measurement without bore. The phase diagrams are characteristic for the wood material. At low frequency the phase starts on the minimum values and then it increases until $100 \mathrm{~Hz}$ before it decreases and increases again. The dynamic range of phase alternation is $9.89^{\circ}$.

Figure 5 clearly shows the differences between experimental cases. The hole drilled into the log in physical aspect is equivalent to placing a non-conductive media into a conductive. This coarse intervention should result in significant change in the measured attenuation. This can be seen in Figure 5 as well. The smallest attenuation values were measured without an anomaly. Then with the addition of non-conductive media, the attenuation values increase 
consequently. The experimental cases can easily be distinguished in Figure 5. The correlation of attenuation curves and the size of the bore can be clearly seen. The phase values indicate the anomaly clearly as well. By increasing the diameter of non-conductive media at low frequency, the phase is decreasing. Between $1 \mathrm{~Hz}$ and $4 \mathrm{kHz}$ the phase curves have nearly the same values. Thus in this frequency range, the phase measurement isn't capable of distinguishing the diameter of an anomaly. At higher frequencies the phase curves become separated and they indicate the diameter of non-conducting media. Contrary to the change at low frequencies, at a higher frequency range according to the increasing diameter of an anomaly, the phase curves shift to higher values. It is evident that phase measurement provides new information about the investigation of trees and wood material. If an anomaly exists in investigated media, the measured phase curves will characterise the anomaly. Thus by combining the tomographic measurement with the recording of the transfer function of investigated tree or wood material, a characterisation of an existing anomaly can be gained.
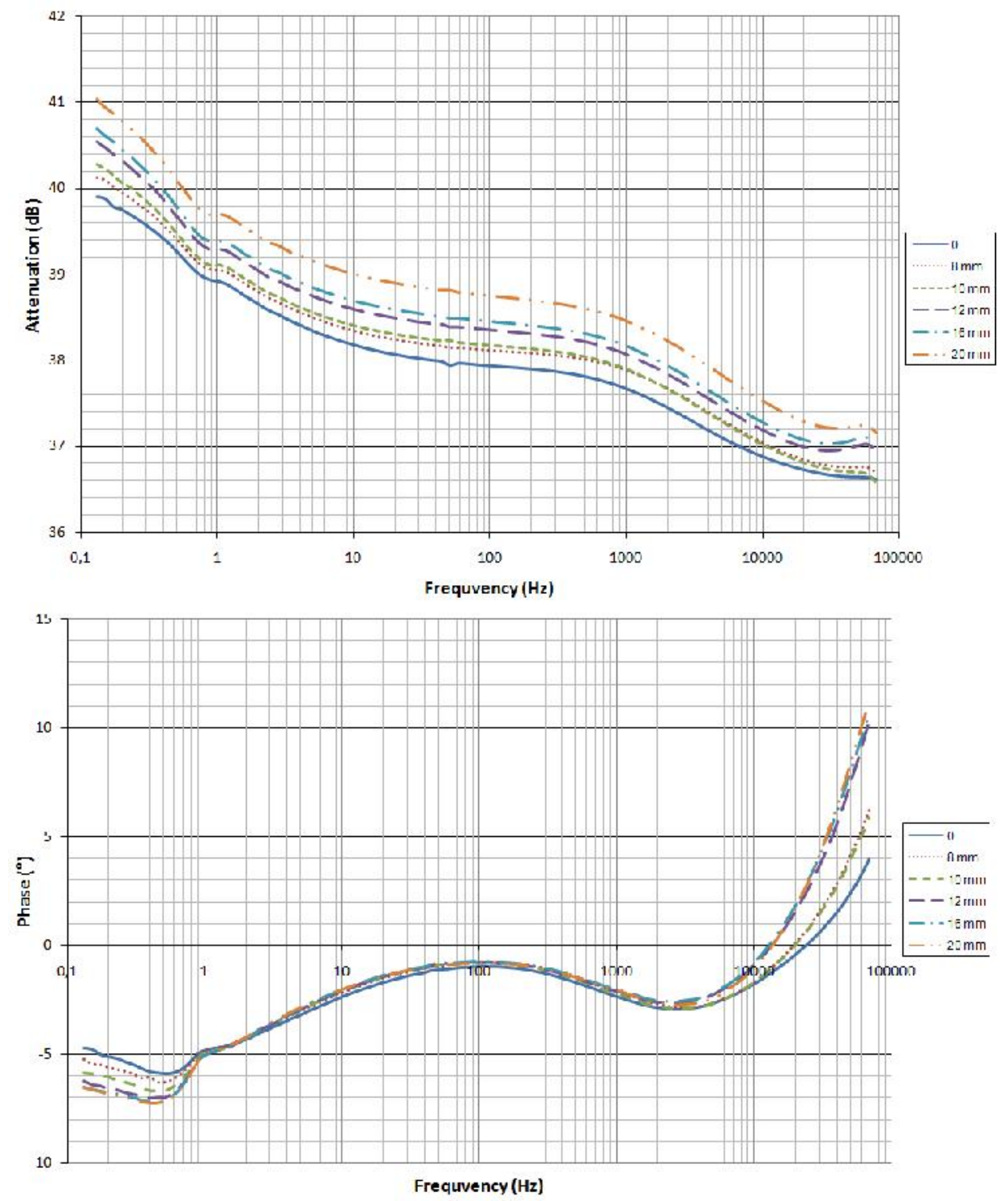

Figure 5. Transfer functions measured in hornbeam log without $(0)$ and with non-conducting media of several diameters 
The obtained results clearly show that the multi-frequency approach offers more extended information about the investigated wood material than the traditional EIT, or ERT methods. Evaluating the attenuation of measured signals represents a possibility to draw conclusions about electrical properties, size and shape of an investigated anomaly. The published experiment shows that the attenuation curves (Figure 5) - according to the results performed without a bore - are in correlation with the diameter of bores: with the increasing diameter of a bore, the difference of actual and 0 curves is increasing. The phase curves (Figure 5) represent the extended information, which is a result of multi-frequency investigation. The 0 curve is characteristic for wood material. With the addition of an anomaly, a non-conductive media (bore), the shape of phase curves became distorted. This alteration is in correlation with material properties of the added anomaly. The phase curves can be examined in low, middle, and high frequency intervals because the response of curves is different in these intervals. This is an important opportunity for enhancing the selectivity of measurement.

Summarising the results: using the multi-frequency approach offers a possibility to develop a mfEIT tool for tree evaluation with better - at least $4 \%$ - spatial resolution compared to the $10 \%$ reported in the literature, Beck (1996).

Acknowledgements: We wish to thank to foresters Ádám Borbás and Árpád Borbás for providing the materials and the circumstances with which the experiments were realized in addition to their assistance in the implementation of the measurements.

\section{REFERENCES}

BECK M. S. - Williams R. (1996): A.: Process tomography: a European innovation and its applications, Measurement Science and Technology (7): 215 - 224.

BIEKER D. - RUST S. (2010): Electric resistivity tomography shows radial variation of electrolytes in Quercus robur, NRC Research Press, 1189 - 1193. DOI: 10.1139/X10-076,

BIEKER D. - RUST S. (2010): Non-Destructive Estimation of Sapwood and Heartwood Width in Scots Pine (Pinus sylvestris L.), Silva Fennica 44 (2): 267-273.

BIEKER D. - KEHR R. - WEBER G. - RUST S. (2010): Non-destructive monitoring of early stages of white rot by Trametes versicolor in Fraxinus excelsior, Ann. For. Sci. 67 (2): 210, DOI: $10.1051 /$ forest/2009103.

BRAZEE N. J. - MARRA R. E. - GÖCKE L. - WASSENAER P. V. (2011): Non-destructive assessment of internal decay in three hardwood species of north-eastern North America using sonic and electrical impedance tomography, Forestry, 84 (1): 33-39. DOI:10.1093/forestry/cpq040

BUCUR V. (2003): Techniques for high resolution imaging of wood structure: a review, Measurement Science and Technology, 14 (12): 91-98. DOI:10.1088/0957-0233/14/12/R01.

Divós F. - CSUPOR K. - BRÖKER F. (1991): Ultrasonic and Stress Wave based Non-destructive Testing of Wood. In: Proc. 8th International Symp. on Nondestructive Testing of Wood, Vancouver, WA: 272.

Divós F. (1992): Roncsolásmentes Faanyagvizsgálati Szimpózium [The International Symposium on Non-destructive Testing of Wood] Faipar, 40 (1): 11-12. (in Hungarian)

Divós F. - SugiamA M. (1993): Longitudinal Stress Waves for Detecting the Presence, Location and Size of Defects in Wood and Wood based Composites. 9th International Symposium on Nondestructive Testing of Wood, Madison, WI: 218-219.

Divós F. - MÉSZÁROS K. (1994): Root Decay Detection by Stress Wave Technique. In: Proc. of the First European Symposium on Nondestructive Evaluation of Wood, Sopron, Hungary: 524.

Dubbel V. - Weihs U. - KRUMMHEUER F. - Just A. (1999): Neue Methode zu 2-dimensionalen Darstellung von Fäulen an Fichte. AFZ/Der Wald (26): 1422-1425

GERGELY L. - Divos F. (2000): Possibility of glue-defect detection in solid wood panels with ultrasound. In: Proccedings of the 12th International Symposium on Nondestructive Testing, Sopron: 453. 
Nicolotti G. - Socco L. V. - MARTinis R. - Godio A. - SAmbuelli L. (2003): Application and comparison of three tomographic techniques for detection of decay in trees. Journal of Arboriculture 29 (2): 66-78.

OH T. I. - Koo H. - LeeK. H. - Kim S. M. - LeE J. - Kim S. W. - SeO J. K. - Woo E. J. (2008): Validation of a multi-frequency electrical impedance tomography (mfEIT) system KHU Mark1: impedance spectroscopy and time-difference imaging, IOP PUBLISHING, Physiol. Meas. 29: 295-307.

Shortle W. C. - SMith K. T. (1987): Electrical Properties and Rate of Decay in Spruce and Fir Wood, American Phytopathological Society, Phytopathology 77 (6): 811-814.

SZAlai S. - SZARKA L. - PRACSER E. - BosCh F. - Muller I. - TURberG P. (2002): Geoelectric mapping of near-surface karstic fractures by using null arrays, Geophysics 67 (6): 1769-1778.

TANAKA T. - DivÓS F. (2000): Wood Inspection by thermography. In: Proceedings of the 12th International Symposium on Nondestructive Testing, Sopron: 439-447.

VARGA A. - MATUSIK A. - Kiss E. - DivÓs F. (2000): Use of medical CT to qualify wood defects, Proccedings of the 12th International Symposium on Nondestructive Testing, Sopron: 466.

WEIHS, U. (2001): Farbkerndiagnose am stehenden Elsbeerenstamm, AFZ/Der Wald, (6): 268-270.

WoO E. J. (2007): Impedance Spectroscopy and Multi-Frequency Electrical Impedance Tomography, International Journal of Bioelectromagnetism, 9 (2) 101-102. 
